\title{
Warm Island Effect in the Badain Jaran Desert Lake Group Region Inferred from the Accumulated Temperature
}

\author{
Xiaoyan Liang, Liqiang Zhao, Zhenmin Niu, Xingbin Xu, Nan Meng and Nai'ang Wang * \\ Center for Glacier and Desert Research, College of Earth and Environmental Sciences, Lanzhou University, \\ Lanzhou 730000, China; liangxy16@lzu.edu.cn (X.L.); zhaolq@lzu.edu.cn (L.Z.); niuzhm09@1zu.cn (Z.N.); \\ xuxb15@lzu.edu.cn (X.X.); mengn19@lzu.edu.cn (N.M.) \\ * Correspondence: wangna@lzu.edu.cn
}

Received: 15 December 2019; Accepted: 29 January 2020; Published: 30 January 2020

\begin{abstract}
The Badain Jaran Desert (BJD) is characterized by the coexistence of over 110 perennial lakes and thousands of megadunes in its southeast part. Unlike the cold island effect, we found a special phenomenon of the warm island effect in the lake group region of the BJD. However, the concept and formation mechanism remains unclear. In this study, based on observations of land surface processes in the area, we first used the daily mean temperature from 23 automated meteorological stations from 2010 to 2017 to calculate the mean daily temperature $(T) \geq 0{ }^{\circ} \mathrm{C}, T \geq 10^{\circ} \mathrm{C}$ accumulated temperature and negative accumulated temperature. Furthermore, using the net radiation from two eddy covariance measurement systems, characteristics of the net radiation between the lake and megadunes were analyzed. When comparing observed data in the lake group region to surrounding areas, accumulated temperature from all three meteorological stations in the lake group region were higher; the duration days of $T \geq 0{ }^{\circ} \mathrm{C}$ and $T \geq 10^{\circ} \mathrm{C}$ were longer, whereas duration days of negative accumulated temperature were shorter. In addition, the initial dates for $T \geq 0{ }^{\circ} \mathrm{C}$ and $T \geq 10^{\circ} \mathrm{C}$ accumulated temperature were earlier, whereas the end dates were delayed. Variations in heat were observed between stations in the lake group region that may be reflective of microclimate environments between lakes. The authors relate warm island formation in the BJD lake group region to (1) the heat carried by groundwater recharge to the desert lake groups has a great impact on the local temperature. (2) Net heat radiation to the atmosphere through sensible heat flux owing to sparse vegetation in the desert areas. Hence, heat resources are richer in the lake group region. This study aims to improve our understanding of the warm island effect from a comprehensive analysis of its intensity and distribution pattern around the lake group region as compared to its surroundings. In addition, the results from this study will provide a scientific basis for determining the source of lake water in the BJD.
\end{abstract}

Keywords: Badain Jaran Desert; lake group region; warm island effect; field observation; land surface processes

\section{Introduction}

Climate and climate variability are determined by the amount of incoming solar radiation, chemical composition and dynamics of the atmosphere, and surface characteristics of the earth [1-3]. The surface characteristics of the earth often affect the regional and local patterns of climate through the redistribution of energy [4-6]. As a unique underlying surface covering about $40 \%$ of terrestrial surface, deserts make a vital contribution to the global climate system [6-8]. In spite of the popular perception of their uniformity over vast distances, deserts often contain a complex mosaic of microclimates and 
local weather. Great contrasts also exist in the climate and surface characteristics from one desert to the next [9-13]. Thus, understanding the desert climates is essential because of strong linkages between climate, biological processes, and geomorphology [14-20].

In China, arid regions are mainly distributed over the northwestern areas, covering about $24.5 \%$ of the Chinese territory [20]. It has been reported that the ecological environment in these areas is sensitive to global climate change and human activities [21,22]. The Badain Jaran Desert (BJD) is located on the northwestern Alxa Plateau in north-central China. Extending over an area of $5.2 \times 10^{4} \mathrm{~km}^{2}$, the BJD is the second largest desert in China [23]. It is characterized by the coexistence of more than 110 perennial lakes and thousands of megadunes. Because of its unique desert environment, the BJD has received continuous attention from many researchers [24-28]. However, conclusions regarding the water source of the lakes in the BJD remain controversial. Previous researchers primarily applied hydrogeochemical methods to study the lakes and groundwater in the BJD. Due to harsh environmental conditions, there is a lack of long-term, in situ observations of land surface processes in the BJD interior and surrounding areas $[20,29]$. Little research has been conducted on how these lakes influence the local climate. The traditional view holds that an oasis or lake in the desert or Gobi is a cold source, namely, the cold island effect [30]. However, in the southeastern margin of the BJD, there are over 110 perennial lakes spread among the megadunes, here referred to as the BJD lake group area. Zhang et al. (2015) found that the lake group area surface temperature in the hinterland of the BJD was significantly higher than that in other regions of the desert (i.e., a "warm island effect") [31]. Evidently, the traditional theory on the cold island effect cannot explain its formation mechanism. Research on urban heat island effects has shown that the background temperature affecting the performance of cool/hot sources, such as water, is not sufficient in mitigating urban heat island effects in high-rise and high-density built areas because of their small areas [32]. However, the warm island effect in the BJD, referring to the land surface temperature in lake group region, is higher than that in other regions of the deserts. As remote sensing data have a lower spatial and temporal resolution than the in-situ observations, it is necessary to use the observations of land surface processes to reveal the warm island effect and its generative mechanism. Study on the role of lakes in increasing the local temperature will provide further insight into their water source. The heat is mainly carried by the deep groundwater during the process of recharge lakes, not by other sources. Revealing the phenomenon, especially the formation mechanism of the warm island effect, will provide a new perspective for solving the water resources of the lakes in the BJD. At the same time, it will enrich the concept of the warm island effect based on the observational data.

The aim of this paper is to reveal the phenomenon of the warm island effect and its formation mechanism based on the observations of land surface processes. Based on this aim, we used the mean daily temperature data from 2010 to 2017 from 23 meteorological stations in and around the BJD to calculate the mean daily temperature $(T) \geq 0{ }^{\circ} \mathrm{C}$ and $T \geq 10^{\circ} \mathrm{C}$ accumulated temperature and negative accumulated temperature. In addition, the characteristics of the net radiation in the study area were examined from a radiation balance perspective. Results from this research will offer a reliable basis to characterize the warm island effect in the BJD from its intensity and distribution pattern and will provide scientific evidence for determining the source of lake water in the BJD.

\section{Materials and Methods}

\subsection{Study Area}

The BJD ( $\left.39^{\circ} 04^{\prime} 15^{\prime \prime} \mathrm{N}-42^{\circ} 12^{\prime} 23^{\prime \prime} \mathrm{N}, 99^{\circ} 23^{\prime} 18^{\prime \prime} \mathrm{E}-104^{\circ} 34^{\prime} 02^{\prime \prime} \mathrm{E}\right)$ is located in the northwestern Alxa Plateau of the western Inner Mongolia autonomous region (Figure 1). It is surrounded by the ancient Juyan and Guaizi lakes to the north, the ancient Gurinai Lake and the Zhengyi Gorge of the Heihe River to the west, and the Yabrai Mountain to the southeast [33]. The Hexi Corridor and Qilian Mountains are in the southeastern part of the desert. Covering an area of $5.2 \times 10^{4} \mathrm{~km}^{2}$, the BJD is the second largest desert in China [23]. The BJD climate is extremely continental [34]; annual mean 
temperature increases from $7.7^{\circ} \mathrm{C}$ in the southeast to $8.2^{\circ} \mathrm{C}$ in the northwest. Regional annual mean precipitation is $77 \mathrm{~mm}$, mainly occurring from July through September. The lake group region of the BJD is formed from a $10 \mathrm{~km}$ buffer zone centered on the lakes [31]. It is a regional coexistence of more than 110 perennial lakes and thousands of megadunes (large sand dunes, typically 200-300 m high) $[24,35]$. The largest lake has an area of $2.32 \mathrm{~km}^{2}$, whereas the majority is smaller than $0.5 \mathrm{~km}^{2}$. Most of the lakes are hypersaline, with total dissolved solids (TDS) of up to $300 \mathrm{~g} / \mathrm{L}$, owing to the high evaporation rates. By contrast, the springs and groundwater from the deep wells are all fresh water with TDS below $1 \mathrm{~g} / \mathrm{L}$ and serve as critical water sources for wildlife and humans living in the desert [36,37].

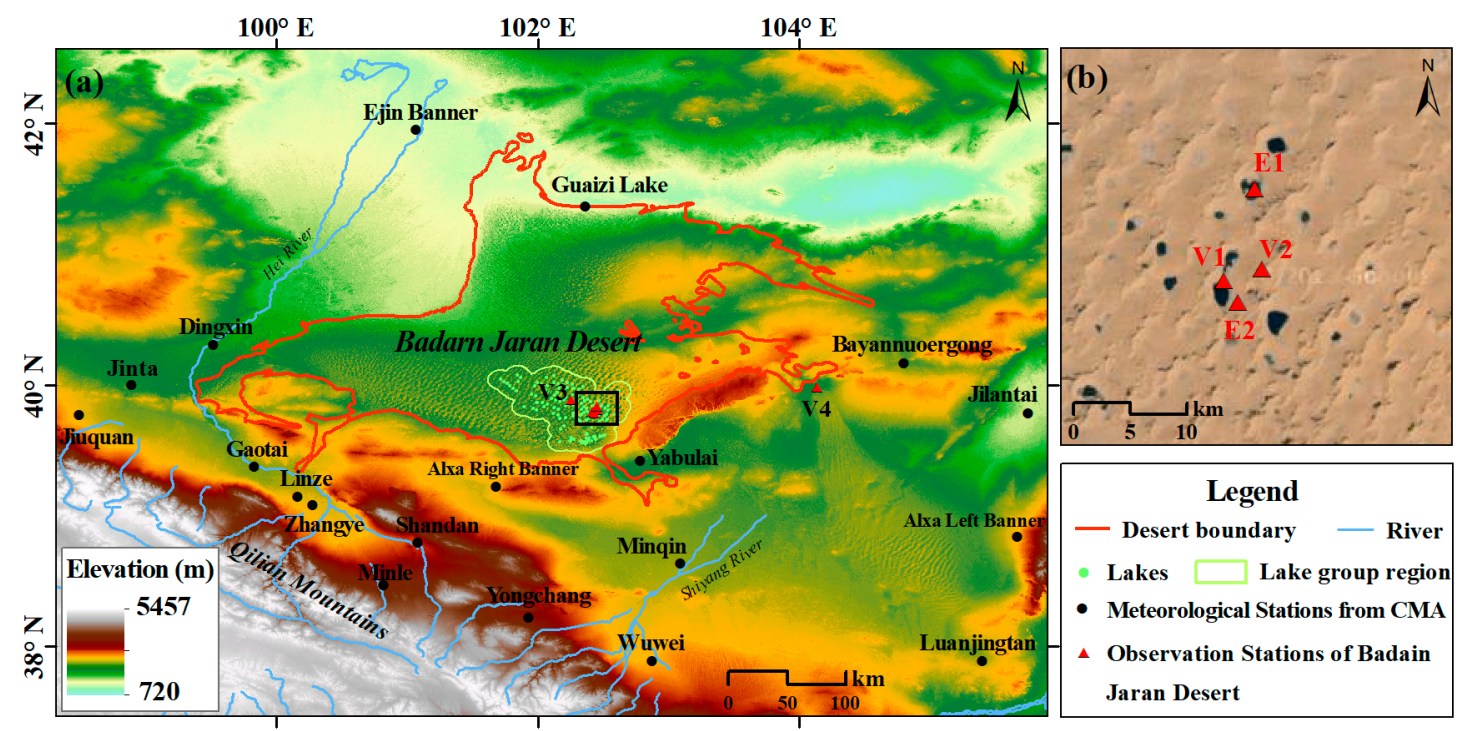

Figure 1. Data collection stations: (a) the distribution of meteorological stations in the BJD and (b) observation stations in the lake group area.

\subsection{Data Collection}

Daily mean temperature was provided by automated meteorological data recorders from Lanzhou University field scientific experimental stations (V1, V2, V3, and V4) and China National Climate Center (http://www.cma.gov.cn/en2014/) standard meteorological stations (Figure 1a). Among them, V1, V2, and V3 stations are in the lake group region, while the others are located in the surrounding areas. The V1 station (39.8 $\mathrm{N}, 102.4^{\circ} \mathrm{E}, 1209 \mathrm{~m}$ a.s.1.) is located in a lake basin of two lakes: the Sumubarunjilin Lake and Sumujilin Lake. The V2 station $\left(39.8^{\circ} \mathrm{N}, 102.5^{\circ} \mathrm{E}, 1523 \mathrm{~m}\right.$ a.s.l.) is located on flat sandy land on the top of a megadune. The V3 station $\left(39.9^{\circ} \mathrm{N}, 102.3^{\circ} \mathrm{E}, 1166 \mathrm{~m}\right.$ a.s.l.) is located in a lake basin of the Cherigele Lake. The V4 station $\left(40.0^{\circ} \mathrm{N}, 104.1^{\circ} \mathrm{E}, 1215 \mathrm{~m}\right.$ a.s.1.) is located near the Baxingaole Lake in the surrounding areas of BJD. All data were adjusted to a single timeframe as initial observation time differed slightly between the two data collection agencies. Data integrity and continuity were ensured using strict quality control procedures (including the extreme value test and time consistency test) [38]. Practical application showed that the data are satisfactorily stable, reliable, and accurate. The net radiation was measured by a four-component net radiometer (NR01, Hukseflux, Netherlands) with the eddy covariance (EC) measurement system. One of the eddy covariance measurement systems (E1) was located in the center of the Yindeertu Lake, $250 \mathrm{~m}$ from the nearest shore. Another EC measurement system (E2) was located on a nearby flat sandy land on the lower part of a megadune beside the Sumubarunjilin (Figure 1b). Digital Elevation Model (DEM) data, with a spatial resolution of $90 \mathrm{~m}$, were collected from the U.S. Geological Survey (USGS) (http://www.usgs.gov). 


\subsection{Data Analysis}

\subsubsection{Calculation of Accumulated Temperature}

Accumulated temperature over the period 2010-2017 was extracted from daily mean temperature data using the 5-day simple moving average method [39-41]. Start and end dates of $T \geq 0{ }^{\circ} \mathrm{C}$ and $T \geq 10^{\circ} \mathrm{C}$ periods were determined for each meteorological station for each year, and corresponding accumulated temperatures were calculated. This was accomplished in the following manner. For each warm season, we determined the first day on which the mean daily temperature value was not less than the critical temperature, and we examined date of the subsequent 4 days. Average temperatures were then calculated in 5-day increments from that day. The first temperature which was not less than the critical temperature from the longest 5-day moving average temperature series data during the course of a year was selected. The first day of this set for which the mean daily temperature was not lower than that of the critical temperature was selected as the start date of $T \geq 0^{\circ} \mathrm{C}$ and $T \geq 10^{\circ} \mathrm{C}$ Similarly, the last day of the corresponding 5 days for which the mean daily temperature was not lower than that of the critical temperature was selected to represent the end date. The number of days between the start and end dates (inclusive) was determined to be the duration days for $T \geq 0{ }^{\circ} \mathrm{C}$ and $T \geq 10^{\circ} \mathrm{C}$. The sum of the mean daily temperature between the start and end dates was determined to be the accumulated temperature for the duration of $T \geq 0{ }^{\circ} \mathrm{C}$ and $T \geq 10^{\circ} \mathrm{C}$. Negative accumulated temperature refers to the sum of the mean daily temperature which was below $0{ }^{\circ} \mathrm{C}$ in the winter (December to February) and was calculated in the same manner [42].

\subsubsection{Correcting the Daily Mean Temperature}

The influence of longitude, latitude, and altitude had to be accounted for in the analysis of the spatial distribution of accumulated temperature. The daily mean temperatures of all stations were corrected to uniform longitude, latitude, and altitude using a multiple linear regression model [43,44]. The following formula was used:

$$
y=a_{0}+a_{1} x_{1}+a_{2} x_{2}+a_{3} x_{3}
$$

where $y\left({ }^{\circ} \mathrm{C}\right)$ is daily mean temperature, $x_{1}, x_{2}, x_{3}$ are longitude, latitude, and altitude, respectively, and $a_{0}, a_{1}, a_{2}, a_{3}$ are coefficients. The absolute value of $a_{1}, a_{2}, a_{3}$ is the rate of temperature change. In this model, the longitude, latitude, and altitude of the 19 meteorological stations in the surrounding areas of the BJD are the independent variables, and the corresponding daily mean temperature from 2010 to 2017 is the dependent variable. Fitted accumulated temperature data for V1, V2, V3, and V4 stations were calculated using the above regression model (the goodness of fit of the regression equation was $>0.94$, and the equation passed the F-test at the 0.001 confidence level). Then, the fitted values were compared to observed values to reveal the heat difference between the lake group region and the surrounding areas of the BJD.

\subsubsection{Kriging Interpolation}

For many natural phenomena that are associated with space or time, such as the distribution of temperature, the similarity of sample data between adjacent samples is often higher than between remote samples. Kriging interpolation is based on random variables and the establishment of a corresponding structure in space or time; this method is the best linear unbiased estimator (BLUE) for fitted data. After calculating the annual accumulated temperature of all the meteorological stations in the lake group and surrounding areas of the BJD, we established a database that summed the accumulated temperature data and produced coverage files for the BJD area, using ArcGIS for Desktop (Esri, Redlands, CA, USA). Longitude and latitude determined the spatial positions of the meteorological stations. The attributed data of the point layer contained the mean accumulated temperature of each station. The coverage files were imported into the digital elevation model data of the BJD area in ArcGIS and were processed by Kriging interpolation analysis. 


\section{Results}

\subsection{Comparison of Observed and Fitted Values}

Observed and fitted values for $T \geq 0{ }^{\circ} \mathrm{C}$ accumulated temperature are shown in Table 1. Observed values from the V1, V2, and V3 stations represent the thermal resources in the lake group region. Fitted values and observed values from the $\mathrm{V} 4$ station represent the thermal resources in the surrounding areas. The observed values of $T \geq 0{ }^{\circ} \mathrm{C}$ accumulated temperature were all higher than the fitted values. The average values of $T \geq 0{ }^{\circ} \mathrm{C}$ accumulated temperature from the individual V1, V2, and V3 stations were $470.2^{\circ} \mathrm{C}, 505.5^{\circ} \mathrm{C}$, and $300.8^{\circ} \mathrm{C}$ higher, respectively, than the fitted value, while the $\mathrm{V} 4$ station value was $5.7^{\circ} \mathrm{C}$ lower. The observed values of start dates at the V1, V2, and V3 stations were 2, 4, and 2 days earlier, respectively, than the fitted dates, while the V4 station was consistent with the fitted date. End dates at the V1, V2, and V3 stations were 6, 8, and 1 day later than the respective fitted dates, whereas the observed period at the V4 station ended 8 days earlier. Thus, at the V1, V2, and V3 stations, the $T \geq 0{ }^{\circ} \mathrm{C}$ durations were lengthened by 8,12 , and 3 days, while the duration was 8 days shorter at the $\mathrm{V} 4$ station.

Table 1. Comparison of observed and fitted values of $T \geq 0{ }^{\circ} \mathrm{C}$ accumulated temperature.

\begin{tabular}{cccccc}
\hline Station & Comparison & $\begin{array}{c}\text { Accumulated } \\
\text { Temperature }\left({ }^{\circ} \mathbf{C}\right)\end{array}$ & $\begin{array}{c}\text { Start Dates } \\
\text { Month (M)-Day (D) }\end{array}$ & $\begin{array}{c}\text { End Dates } \\
\text { (M-D) }\end{array}$ & $\begin{array}{c}\text { Duration Days } \\
\text { (D) }\end{array}$ \\
\hline \multirow{2}{*}{ V1 } & Observed value & 4724.9 & $3-3$ & $11-22$ & 265 \\
& Fitted value & 4254.7 & $3-5$ & $11-16$ & 257 \\
\hline \multirow{2}{*}{ V2 } & Observed value & 4214.1 & $3-6$ & $11-14$ & 254 \\
& Fitted value & 3708.6 & $3-10$ & $11-6$ & 242 \\
\hline \multirow{2}{*}{ V3 } & Observed value & 4588.1 & $3-5$ & $11-15$ & 256 \\
& Fitted value & 4287.3 & $3-7$ & $11-14$ & 253 \\
\hline \multirow{2}{*}{ V4 } & Observed value & 4178.9 & $3-9$ & $11-7$ & 244 \\
& Fitted value & 4184.6 & $3-9$ & $11-15$ & 252 \\
\hline
\end{tabular}

Observed and fitted values of $T \geq 10^{\circ} \mathrm{C}$ accumulated temperature followed a similar pattern (Table 2). Average observed values of $T \geq 10^{\circ} \mathrm{C}$ accumulated temperature from the individual V1, V2, and V3 stations were $466.2^{\circ} \mathrm{C}, 350.8^{\circ} \mathrm{C}$, and $295.8^{\circ} \mathrm{C}$ higher, respectively, than the fitted values, while the observed accumulated temperature at the $\mathrm{V} 4$ station was only $6.6^{\circ} \mathrm{C}$ lower. The start dates at the V1, V2, and V3 stations were 3, 1, and 2 days earlier, respectively, than the fitted dates, while the V4 station was consistent with the fitted date. The end dates at the V1, V2, and V3 stations were 8, 5, and 4 days later, respectively, than the fitted dates, whereas the duration ended 2 days earlier at the $\mathrm{V} 4$ station. Thus, the duration of $T \geq 10^{\circ} \mathrm{C}$ was lengthened by 11 days at $\mathrm{V} 1$ and by 6 days at $\mathrm{V} 2$ and $\mathrm{V} 3$. The observed duration at the $\mathrm{V} 4$ station was 2 days shorter than the fitted duration.

Table 2. Comparison of observed and fitted values of $T \geq 10^{\circ} \mathrm{C}$ accumulated temperature.

\begin{tabular}{cccccc}
\hline \multirow{2}{*}{ Station } & Comparison & $\begin{array}{c}\text { Accumulated Temperature } \\
\left({ }^{\circ} \mathbf{C}\right)\end{array}$ & $\begin{array}{c}\text { Start Dates } \\
(\mathbf{M}-\mathbf{D})\end{array}$ & $\begin{array}{c}\text { End Dates } \\
(\mathbf{M}-\mathbf{D})\end{array}$ & $\begin{array}{c}\text { Duration Days } \\
(\mathbf{D})\end{array}$ \\
\hline \multirow{2}{*}{ V1 } & Observed value & 4257.1 & $4-2$ & $10-17$ & 199 \\
& Fitted value & 3790.9 & $4-5$ & $10-9$ & 188 \\
\hline \multirow{2}{*}{ V2 } & Observed value & 3539.9 & $4-22$ & $10-12$ & 174 \\
& Fitted value & 3189.1 & $4-23$ & $10-7$ & 168 \\
\hline \multirow{2}{*}{ V3 } & Observed value & 4161.3 & $4-4$ & $10-15$ & 195 \\
& Fitted value & 3865.5 & $4-6$ & $10-11$ & 189 \\
\hline \multirow{2}{*}{$\mathrm{V} 4$} & Observed value & 3730.9 & $4-10$ & $10-6$ & 180 \\
& Fitted value & 3724.3 & $4-10$ & $10-8$ & 182 \\
\hline
\end{tabular}


Observed and fitted values of $T<0{ }^{\circ} \mathrm{C}$ negative accumulated temperature are shown in Table 3. Negative accumulated temperatures at the V1, V2, and V3 stations were $127.0^{\circ} \mathrm{C}, 176.0^{\circ} \mathrm{C}$, and $48.1^{\circ} \mathrm{C}$ higher, respectively, than the fitted values. In contrast, the observed accumulated temperature at the V4 station was $144.8^{\circ} \mathrm{C}$ lower than the fitted value. The duration of negative accumulated temperature at the V1, V2, and V3 stations was 14, 10, and 2 days shorter, respectively, than the fitted durations, while at the V4 station, the duration was lengthened by 2 days.

Table 3. Comparison of observed and fitted values of negative accumulated temperature.

\begin{tabular}{cccc}
\hline Station & Comparison & Negative Accumulated Temperature $\left({ }^{\circ} \mathbf{C}\right)$ & Duration Days (D) \\
\hline \multirow{2}{*}{ V1 } & Observed value & -520.3 & 79 \\
& Fitted value & -647.3 & 85 \\
\hline \multirow{2}{*}{ V2 } & Observed value & -505.9 & 77 \\
& Fitted value & -681.9 & 87 \\
\hline \multirow{2}{*}{ V3 } & Observed value & -531.6 & 81 \\
& Fitted value & -579.7 & 83 \\
\hline \multirow{2}{*}{ V4 } & Observed value & -718.0 & 87 \\
& Fitted value & -573.2 & 85 \\
\hline
\end{tabular}

\subsection{Spatial Distribution Analysis}

Figure 2 shows the spatial distribution maps of $T \geq 0{ }^{\circ} \mathrm{C}$ accumulated temperature and duration days obtained by interpolating 2010-2017 data from the 23 meteorological stations in the study region. The influences of longitude, latitude, and altitude on the spatial distribution maps were eliminated using the multiple linear regression model. The general trend of intensifying (dark areas) accumulated temperature and increasing (dark areas) duration days was circularly distributed and centered on the lake group region. The $T \geq 0{ }^{\circ} \mathrm{C}$ accumulated temperature in the lake group region was $412.4^{\circ} \mathrm{C}$ higher than in surrounding areas (Figure $2 \mathrm{a}$ ). $\mathrm{T} \geq 0{ }^{\circ} \mathrm{C}$ duration was 9 days longer than in surrounding areas (Figure $2 b$ ). Therefore, the heat resources in the lake group region in the southeastern part of BJD are richer than in the surrounding areas.
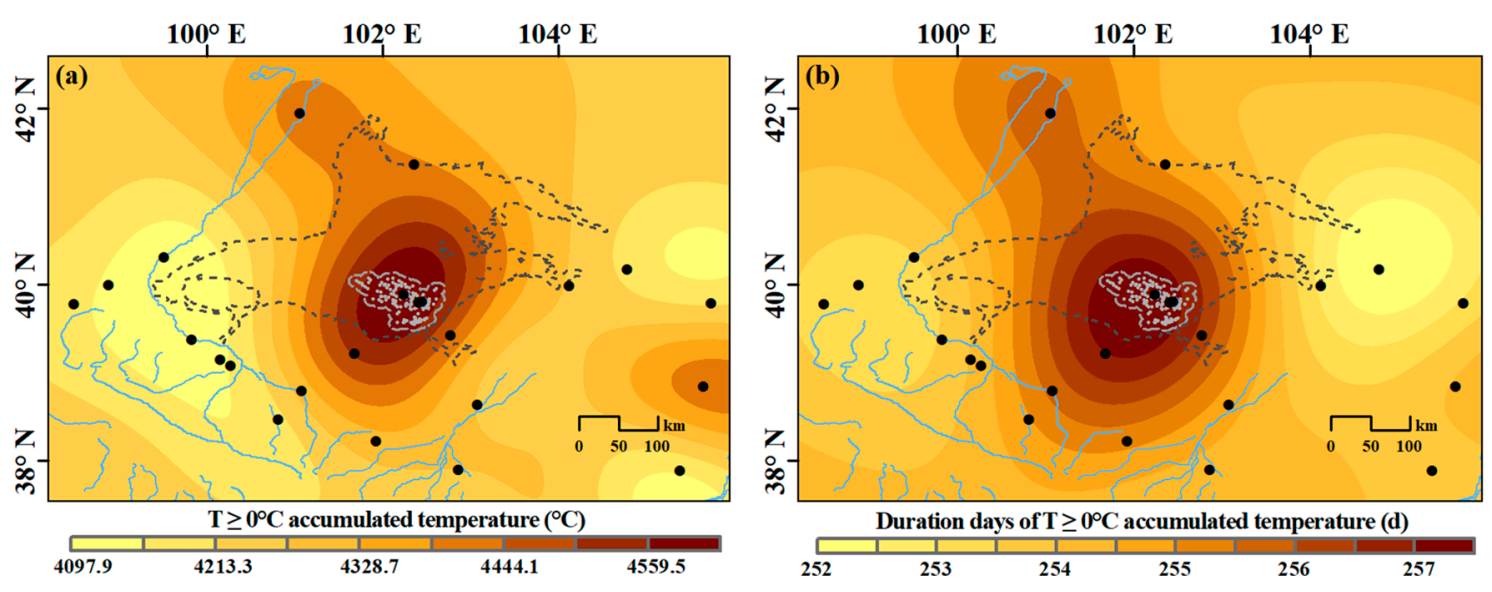

Figure 2. (a) Spatial distribution of $T \geq 0{ }^{\circ} \mathrm{C}$ accumulated temperature and (b) duration days from 2010 to 2017 over the BJD study area.

Figure 3 shows the spatial distribution maps for $T \geq 10^{\circ} \mathrm{C}$ accumulated temperature and duration days obtained by interpolating 2010-2017 data from the 23 meteorological stations in the study region. The $T \geq 10^{\circ} \mathrm{C}$ accumulated temperature in the lake group region was $429.5^{\circ} \mathrm{C}$ higher than in surrounding areas, especially at the same latitude (Figure 3a). Duration in the lake group region was 12 days longer than in surrounding areas (Figure 3b). The intensified accumulated temperature 
and increasing duration days are located in the lake group region. An additional high sub-high value center for the duration period is located around the Ejin Banner at $42^{\circ} \mathrm{N}$.
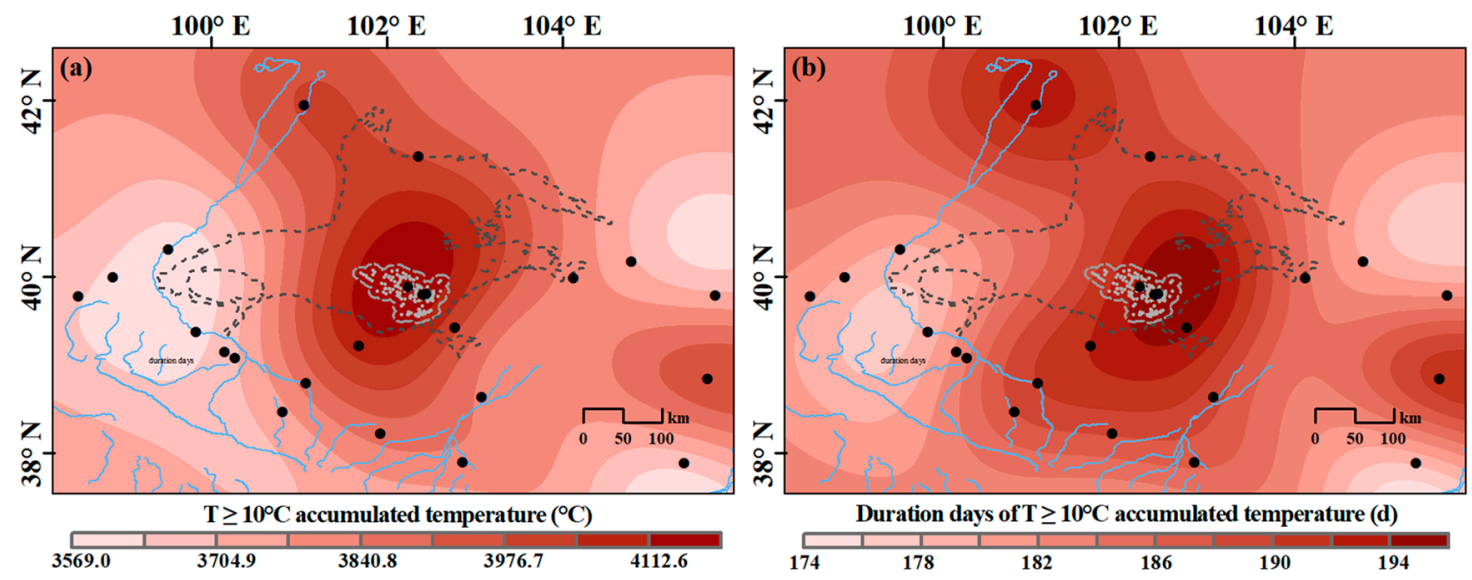

Figure 3. (a) Spatial distribution of $T \geq 10{ }^{\circ} \mathrm{C}$ accumulated temperature and (b) duration days from 2010 to 2017 over the BJD study area.

The thermal resource distribution in the winter is represented in Figure 4 by spatial distribution maps of negative accumulated temperature and duration days from 2010 to 2017. The maps show that high (dark areas in Figure 4a) values of negative temperature and short (white areas in Figure 4b) duration are mainly distributed in the lake group region in the southeastern part of BJD. Conversely, there are two low-value centers at the same latitude.
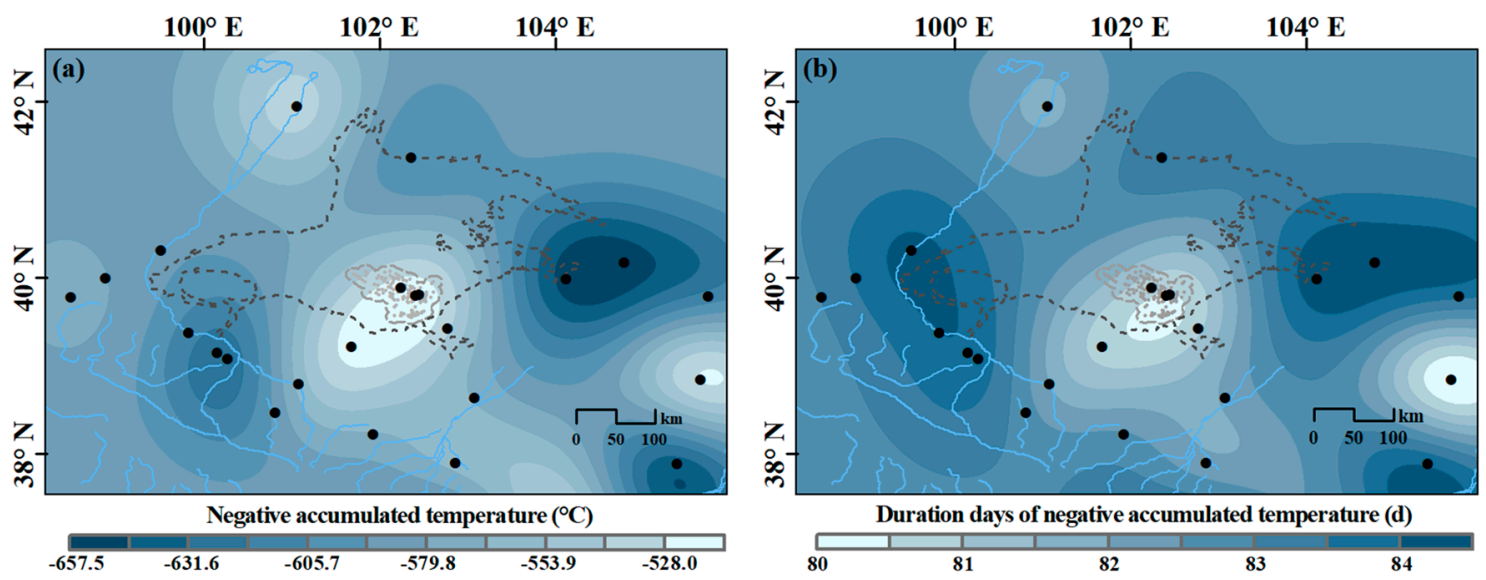

Figure 4. (a) Spatial distribution of negative accumulated temperature and (b) duration days from 2010 to 2017 over the BJD study area.

\section{Discussion}

\subsection{Reason for the Warm Island Effect}

Net radiation is defined as the difference between incoming and outgoing radiation fluxes, including long and shortwave radiation, at the Earth's surface [45]. It is a key quantity for the estimation of surface energy budget and is mainly affected by sunshine duration, weather conditions, and the underlying surface [46]. In this study, we calculated the seasonal net radiation at E1 and E2 stations (Figure 5). Results show that the net radiation at E1 station was much higher than at E2 station and exhibited large fluctuations and seasonal dynamics. Such results point out the significantly greater ability of lakes to store energy as compared to dunes. Thus, under the unique dune-lake landscape of BJD, the difference in net radiation will inevitably lead to uneven heat distribution [47-50]. 
Consequently, the local air circulation between lakes and megadunes will affect the spatial distribution pattern of heat resource by way of air movements [19].

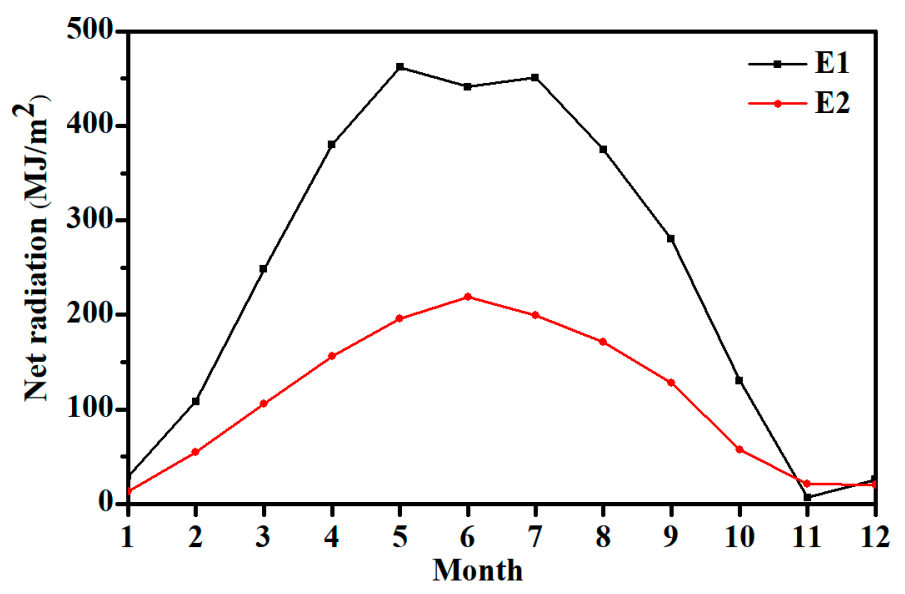

Figure 5. Seasonal net radiation of E1 and E2 stations in the BJD.

According to $\mathrm{Hu}$ (2015a), the average turbulent heat flux at E1 station from 2012 to 2013 was $120.0 \mathrm{~W} / \mathrm{m}^{2}$, but the net radiation was only $87.7 \mathrm{~W} / \mathrm{m}^{2}$ [49]. This result was confirmed by Ma et al. (2015) [51]. As shown in Table 4, the net radiation was less than the sum of the sensible heat flux and the latent heat flux at the lake surface. This implies that other energy supplies to the lake cannot be ignored.

Table 4. Daily integral value of the energy flux on land and lake surface under different weather conditions (MJ·m ${ }^{-2}$ ) (Ma et al., 2015).

\begin{tabular}{cccccccc}
\hline & \multicolumn{4}{c}{ land Surface } & \multicolumn{3}{c}{ Lake Surface } \\
\cline { 2 - 8 } Weather & $\begin{array}{c}\text { Net } \\
\text { Radiation }\end{array}$ & $\begin{array}{c}\text { Sensible } \\
\text { Heat Flux }\end{array}$ & $\begin{array}{c}\text { Latent } \\
\text { Heat Flux }\end{array}$ & $\begin{array}{c}\text { Soil Heat } \\
\text { Flux }\end{array}$ & $\begin{array}{c}\text { Net } \\
\text { Radiation }\end{array}$ & $\begin{array}{c}\text { Sensible } \\
\text { Heat Flux }\end{array}$ & $\begin{array}{c}\text { Latent Heat Flux } \\
\text { Heat }\end{array}$ \\
\hline Sunny Day & 7.3 & 5.4 & 0.5 & 1.1 & 16.0 & -0.4 & 19.0 \\
Partly Cloudy & 7.0 & 4.2 & 1.1 & 1.2 & 14.7 & -1.3 & 15.6 \\
Cloudy Day & 4.4 & 2.3 & 1.6 & -0.5 & 7.7 & -0.1 & 16.0 \\
Rainy Day & 2.2 & 1.7 & 3.0 & -3.2 & 1.0 & 1.0 & 11.0 \\
\hline
\end{tabular}

Zhang et al. (2016) found that the spring water temperature of the BJD in January 2014 was much higher than the soil and atmosphere temperatures (Table 5) [31]. Thus, influenced by local circulation, the heat and energy stored in the lake will inevitably have a great impact on the local temperature. Further observation and research are needed on the sources of this energy, its magnitude, and the intensity of its effects.

Table 5. Spring water temperature of BJD in January 2014 (Zhang et al., 2015).

\begin{tabular}{cccc}
\hline Site & Temperature $\left({ }^{\circ} \mathbf{C}\right)$ & Site & Temperature $\left({ }^{\circ} \mathbf{C}\right)$ \\
\hline Habutenuoer Lake & 17.9 & Zhaoergetu Lake & 17.7 \\
Xibayannuoer Lake & 16.9 & Yihejigede Lake & 17.2 \\
Xinuoertu Lake & 13.7 & Taolaitu Lake & 17.3 \\
Gelitu Lake & 14.9 & Sumujilin Lake & 14.2 \\
Naogunnuoer Lake & 17.3 & Barunjilin Lake & 16.5 \\
Taosijilin Lake & 17.3 & Bilutu Lake & 14.6 \\
Zhongbayannuoer Lake & 17.3 & & \\
\hline
\end{tabular}


In addition, the partitioning of available energy transformed into sensible and latent heat fluxes is dependent on both the biological and climatological conditions of an ecosystem. In the BJD hinterland, the vegetation is sparse; hence, calorific expenditure through transpiration is at a low level, resulting in reduced heat expenditure through evaporation at the surface. According to Oke (1978), in arid desert areas, approximately $90 \%$ of the net radiation is transmitted to the atmosphere through sensible heat flux [52]. Therefore, the heat resource in the lake group region was richer than in surrounding areas.

\subsection{Implications of the Research}

The BJD in north-central China has a unique landscape that contains hundreds of lakes and the highest sand dunes in the world. However, the explanation of the source of water in this desert remains controversial, and the origin and flow processes of groundwater are unclear. There are currently at least five hypotheses regarding the source of lake water in this region:

1. Local precipitation and condensed water [53];

2. Residual water from precipitation and snowmelt during past humid periods (e.g., the mid-Holocene or the Late Pleistocene) [54];

3. Subsurface runoff from precipitation on nearby mountains (e.g., the Yabulai Mountains and Beida Mountains) [25,34,55];

4. Deep strata in the adjacent fracture zone recharging the desert lake group from the southeast along an altitudinal gradient [26,28]; and

5. Deep circulating groundwater from the Qilian Mountains and the Tibetan Plateau through deep faults [24].

Most researchers primarily applied hydrogeochemical methods to study the lakes and groundwater in the BJD, but fewer land surface process observations were used to reveal the source of the lakes. This research contributes to a better understanding of the warm island effect, its intensity, and distribution pattern by using accumulated temperature to represent the local heat resource. We believe that the warm island effect is primarily related to the heat carried from remote groundwater recharge lakes. Because only deep groundwater can carry the heat during the process of recharge lakes, this implies that the warm island effect will provide another scientific basis for the conclusion of groundwater recharge lakes. Therefore, groundwater is suggested to be the primary recharge source of the lake group. However, further investigation of the warm island effect is necessary in order to understand water sources that sustain the aquifer and the lakes in the BJD.

\section{Conclusions}

In this study, we used the daily mean temperature data of 23 meteorological stations in and around the Badain Jaran Desert (BJD) from 2010 to 2017 to calculate the $T \geq 0{ }^{\circ} \mathrm{C}$ and $T \geq 10{ }^{\circ} \mathrm{C}$ accumulated temperature and negative accumulated temperature. Research shows that all observed accumulated temperatures at the three stations in the lake group region were higher than in surrounding areas. Similarly, duration days of $T \geq 0{ }^{\circ} \mathrm{C}$ and $T \geq 10^{\circ} \mathrm{C}$ were longer in the lake group region than in surrounding areas, while duration days of negative accumulated temperature were shorter than in surrounding areas. Variation in heat resources between stations in the lake group region may be related to the micro-climatic environment of these lakes. The results of this study enrich the concept of the warm island effect in the lake group region of the BJD.

The mechanism of the warm island effect in BJD is related to two aspects. Firstly, the heat carried by the groundwater recharge to the desert lake groups. This has a great impact on the local temperature and air circulation between lakes and megadunes, affecting the distribution pattern of heat resources. Therefore, groundwater is suggested to be the primary recharge source of the lake group. Secondly, due to the sparse vegetation and arid surface of the desert hinterland, most of the net radiation to the atmosphere occurs through sensible heat flux. Consequently, the heat resource is richer in the lake group region than in the surrounding areas. This study aims at improving our understanding 
of the warm island effect by analyzing its intensity and distribution pattern. Moreover, it attempts to highlight the need for further research in the region to gain a better understanding of the factors contributing to such a phenomenon.

Author Contributions: N.W. proposed the idea and designed the study. L.Z. and N.M. contributed to the field work. X.X. and Z.N. implemented the methods and analyzed the results. X.L. wrote the main manuscript text. All authors have read and agreed to the published version of the manuscript.

Funding: This research was supported by the Key Project of National Natural Science Foundation of China (No.41530745) and the Fundamental Research Funds for the Central Universities (No. lzujbky-2017-it88, lzujbky-2019-kb42).

Acknowledgments: We thank the Chinese Meteorological Agency for providing weather data.

Conflicts of Interest: The authors declare no conflicts of interest.

\section{References}

1. Chapin, F.S.; Matson, P.A.; Mooney, H.A. Principles of Terrestrial Ecosystem Ecology; Springer: New York, NY, USA, 2002; pp. 18-45.

2. Levitus, S.; Antonov, J.I.; Wang, J.; Delworth, T.L.; Dixon, K.W.; Broccoli, A.J. Anthropogenic Warming of Earth's Climate System. Science 2001, 292, 267-270. [CrossRef]

3. Wang, K.C.; Dickinson, R.E. A review of global terrestrial evapotranspiration: Observation, modeling, climatology, and climatic variability. Rev. Geophys. 2012, 50, RG2005. [CrossRef]

4. Bartlein, P.J.; Harrison, S.P.; Izumi, K. Underlying causes of Eurasian midcontinental aridity in simulations of mid-Holocene climate. Geophys. Res. Lett. 2017, 44, 9020-9028. [CrossRef] [PubMed]

5. Chen, L.; Ma, Z.G.; Zhao, T.B. Modeling and analysis of the potential impacts on regional climate due to vegetation degradation over arid and semi-arid regions of China. Clim. Chang. 2017, 144, 461-473. [CrossRef]

6. Xue, Y.K. The Impact of Desertification in the Mongolian and the Inner Mongolian Grassland on the Regional Climate. J. Clim. 1996, 9, 2173-2189. [CrossRef]

7. Laity, J. Deserts and the Desert Environment; Wiley-Blackwell: Hoboken, NJ, USA, 2008; pp. 48-69.

8. Warner, T.T. Desert Meteorology, 1st ed.; Cambridge University Press: Cambridge, UK, 2004; pp. 1-4.

9. Huo, W.; He, Q.; Yang, X.H.; Zhao, Y.; Wang, S.G.; Li, Y.H. Characteristics of Sand-dust Weather over Kumtagh Desert during 2007-2008 and the Weather Styles. J. Desert Res. 2011, 31, 1037-1045.

10. Petrie, M.D.; Collins, S.L.; Litvak, M.E. The ecological role of small rainfall events in a desert grassland. Ecohydrology 2015, 8, 1614-1622. [CrossRef]

11. Wang, N.A.; Ma, N.; Chen, H.B.; Chen, X.L.; Dong, C.Y.; Zhang, Z.Y. A preliminary study of precipitation characteristics in the hinterland of Badain Jaran desert. Adv. Water Sci. 2013, 24, 153-160.

12. Labraga, J.C.; Villalba, R. Climate in the Monte Desert: Past trends, present conditions, and future projections. J. Arid Environ. 2009, 73, 154-163. [CrossRef]

13. Quade, J.; Rech, J.A.; Betancourt, J.L.; Latorre, C.; Quade, B.; Rylander, K.A.; Fisher, T.S. Paleowetlands and regional climate change in the central atacama desert, northern chile. Quat. Res. 2008, 69, 343-360. [CrossRef]

14. Herrmann, S.M.; Anyamba, A.; Tucker, C.J. Recent trends in vegetation dynamics in the African Sahel and their relationship to climate. Glob. Environ. Chang. 2005, 15, 394-404. [CrossRef]

15. Mahowald, N.M. Anthropocene changes in desert area: Sensitivity to climate model predictions. Geophys. Res. Lett. 2007, 34, L18817. [CrossRef]

16. Reynolds, J.F.; Smith, D.M.; Lambin, E.F.; Turner, B.L.; Mortimore, M.; Batterbury, S.P.; Downing, T.E.; Dowlatabadi, H.; Fernandez, R.J.; Herrick, J.E.; et al. Global desertification: Building a science for dryland development. Science 2007, 316, 847-851. [CrossRef]

17. Zhao, L.; Han, B.; Lv, S.H.; Wen, L.J.; Meng, X.H.; Li, Z.G. The different influence of the residual layer on the development of the summer convective boundary layer in two deserts in northwest China. Theor. Appl. Climatol. 2016, 131, 877-888.

18. Salguero-Gomez, R.; Siewert, W.; Casper, B.B.; Tielborger, K. A demographic approach to study effects of climate change in desert plants. Philos. Trans. R. Soc. B Biol. Sci. 2012, 367, 3100-3114. [CrossRef] [PubMed]

19. Zhang, K.C.; Cai, D.W.; Ao, Y.H.; An, Z.S.; Guo, Z.C. Local Circulation Maintains the Coexistence of Lake-dune Pattern in the Badain Jaran Desert. Sci. Rep. 2017, 7, 40238. [CrossRef] 
20. Zhang, X.H.; Wang, N.A.; Xie, Z.Y.; Ma, X.L.; Huete, A. Water Loss Due to Increasing Planted Vegetation over the Badain Jaran Desert, China. Remote Sens. 2018, 10, 134. [CrossRef]

21. Goyal, R.K. Sensitivity of evapotranspiration to global warming: A case study of arid zone of rajasthan (India). Agric. Water Manag. 2004, 69, 1-11. [CrossRef]

22. Huang, J.P.; Ji, M.X.; Xie, Y.K.; Wang, S.S.; He, Y.L.; Ran, J.J. Global semi-arid climate change over last 60 years. Clim. Dyn. 2016, 46, 1131-1150. [CrossRef]

23. Zhu, J.F.; Wang, N.A.; Chen, H.B.; Dong, C.Y.; Zhang, H.A. Study on the Boundary and the Area of Badain Jaran Desert Based on Remote Sensing Imagery. Prog. Geogr. 2010, 29, 1087-1094.

24. Chen, J.S.; Li, L.; Wang, J.Y.; Barry, D.A.; Sheng, X.F.; Gu, W.Z.; Zhao, X.; Chen, L. Groundwater maintains dune landscape. Nature 2004, 432, 459-460. [CrossRef] [PubMed]

25. Gates, J.B.; Edmunds, W.M.; Darling, W.G.; Ma, J.Z.; Pang, Z.H.; Young, A.A. Conceptual model of recharge to southeastern Badain Jaran Desert groundwater and lakes from environmental tracers. Appl. Geochem. 2008, 23, 3519-3534. [CrossRef]

26. Wang, N.A.; Ning, K.; Li, Z.L.; Wang, Y.X.; Jia, P.; Ma, L. Holocene high lake-levels and pan-lake period on Badain Jaran Desert. Sci. China 2016, 59, 1633-1641. [CrossRef]

27. Bai, Y.; Wang, N.A.; Liao, K.T.; Klenk, P. Geomorphological evolution revealed by aeolian sedimentary structure in Badain Jaran Desert on Alxa Plateau, Northwest China. Chin. Geogr. Sci. 2011, 21, 267-278. [CrossRef]

28. Dong, C.Y.; Wang, N.A.; Chen, J.S.; Li, Z.L.; Chen, H.B.; Chen, L.; Ma, N. New observational and experimental evidence for the recharge mechanism of the lake group in the Alxa Desert, north-central China. J. Arid Environ. 2016, 124, 48-61. [CrossRef]

29. Chen, Y.N.; Li, Z.; Fan, Y.T.; Wang, H.J.; Deng, H.J. Progress and prospects of climate change impacts on hydrology in the arid region of northwest China. Environ. Res. 2015, 139, 11-19. [CrossRef]

30. Su, C.X.; Hu, Y.J. Cold island effect over oasis and lake. Chin. Sci. Bull. 1988, 33, 1023-1026.

31. Zhang, X.H.; Wang, N.A.; Zhao, L.Q.; Wu, Y.; Liang, X.Y. Spatial distribution of winter warm islands in Badain Jaran Desert based on MODIS data. J. Lanzhou Univ. (Nat. Sci.) 2015, 51, 180-185.

32. He, B.J.; Zhao, Z.Q.; Shen, L.D.; Wang, H.B.; Li, L.G. An approach to examining performances of cool/hot sources in mitigating/enhancing land surface temperature under different temperature backgrounds based on landsat 8 image. Sustain. Cities Soc. 2019, 44, 416-427. [CrossRef]

33. Ma, N.; Wang, N.A.; Zhao, L.Q.; Zhang, Z.Y.; Dong, C.Y.; Shen, S.P. Observation of mega-dune evaporation after various rain events in the hinterland of Badain Jaran Desert, China. Chin. Sci. Bull. 2014, 59, 162-170. [CrossRef]

34. Dong, Z.; Wang, T.; Wang, X.M. Geomorphology of the megadunes in the Badain Jaran Desert. Geomorphology 2004, 60, 191-203. [CrossRef]

35. Zhang, Z.Y.; Wang, N.A.; Wu, Y.; Shen, S.P.; Zhang, X.H.; Chang, J.L. Remote sensing on spatial changes of lake area in Badain Jaran Desert hinterland during 1973-2010. J. Lake Sci. 2013, 25, 514-520.

36. Wu, Y.; Wang, N.A.; Zhao, L.Q.; Zhang, Z.Y.; Chen, L.; Lu, Y.; Lü, X.N.; Chang, J.L. Hydrochemical characteristics and recharge sources of lake nuoertu in the badain jaran desert. Chin. Sci. Bull. 2014, 59, 886-895. [CrossRef]

37. Yang, X.P.; Williams, M.A. The ion chemistry of lakes and late Holocene desiccation in the Badain Jaran Desert, Inner Mongolia, China. Catena 2003, 51, 45-60. [CrossRef]

38. Zhang, X.Q.; Sun, Y.; Mao, W.Y.; Liu, Y.Y.; Ren, Y. Regional Response of Temperature Change in the Arid Regions of China to Global Warming. Arid Zone Res. 2010, 27, 592-599.

39. Liu, X.A.; Yu, G.R.; Fan, L.S.; Li, Z.Q.; He, H.L.; Guo, X.B.; Ren, C.Y. Study on Spatialization Technology of Terrestrial Eco-information in Chin(III): Temperature and Precipitation. J. Nat. Resour. 2004, 19, 818-825.

40. Yan, M.H.; Liu, X.T.; Zhang, W.; Li, X.J.; Liu, S. Spatio-temporal changes of $\geq 10^{\circ} \mathrm{C}$ accumulated temperature in northeastern China since 1961. Chin. Geogr. Sci. 2011, 21, 17-26. [CrossRef]

41. Xu, M.Q.; Li, Z.L. Accumulated temperature changes in desert region and surrounding area during 1960-2013: A case study in the Alxa Plateau, Northwest China. Environ. Earth Sci. 2016, 75, 1276. [CrossRef]

42. Sang, J.R.; Liu, Y.L.; Han, S.T.; Qiu, W. Character of the climate change for the negative accumulated temperature in Ningxia. Sci. Meteorol. Sin. 2007, 27, 202-207.

43. Fang, J.Y. Study on the geographic elements affecting temperature distribution in China. Acta Ecol. Sin. 1992, $12,97-104$ 
44. Dai, S.P.; Li, H.L.; Luo, H.X.; Zhao, Y.F.; Zhang, K.X. Changes of annual accumulated temperature over Southern China during 1960-2011. J. Geogr. Sci. 2015, 25, 1155-1172. [CrossRef]

45. Trenberth, K.E.; Fasullo, J.T.; Balmaseda, M.A. Earth's Energy Imbalance. J. Clim. 2014, 27, 3129-3144. [CrossRef]

46. Bisht, G.; Venturini, V.; Islam, S.; Jiang, L. Estimation of the net radiation using MODIS (Moderate Resolution Imaging Spectroradiometer) data for clear sky days. Remote Sens. Environ. 2005, 97, 52-67. [CrossRef]

47. Hu, W.F.; Wang, N.A.; Zhao, L.Q.; Ning, K.; Zhang, X.H.; Sun, J. Surface energy and water vapor fluxes observed on a megadune in the Badain Jaran Desert, China. J. Arid Land 2015, 7, 579-589. [CrossRef]

48. Sun, J.; Hu, W.F.; Wang, N.A.; Zhao, L.Q.; An, R.; Ning, K.; Zhang, X.H. Eddy covariance measurements of water vapor and energy flux over a lake in the Badain Jaran Desert, China. J. Arid Land 2018, 10, 517-533. [CrossRef]

49. Hu, W.F. Research on Water-Heat Exchange between Land and Air in Badain Jaran Desert Based on Observation. Ph.D. Thesis, College of Earth and Environmental Sciences, Lanzhou University, Lanzhou, China, 2015; pp. 79-83.

50. Hu, W.F.; Wang, N.A.; Zhao, L.Q.; Ning, K.; Zhang, X.H.; Sun, J. Water-heat exchange over a typical lake in Badain Jaran Desert, China. Prog. Geogr. 2015, 34, 1061-1071.

51. Ma, N.; Wang, N.A.; Huang, Y.Z.; Li, H.Y.; Lu, J.W. Characteristics of Radiation Budget and Energy Partitioning on Land and Lake Surface under Different Summer Weather Conditions in the Hinterland of Badain Jaran Desert. J. Nat. Resour. 2015, 30, 796-809.

52. Oke, T.R. Boundary Layer Climates; Routledge: Methuen, MA, USA; Abingdon, UK, 1978.

53. Shao, T.J.; Zhao, J.B.; Zhou, Q.; Dong, Z.B.; Ma, Y.D. Recharge sources and chemical composition types of groundwater and lake in the Badain Jaran Desert, northwestern China. J. Geogr. Sci. 2012, 22, 479-496. [CrossRef]

54. Yang, X.P.; Ma, N.N.; Dong, J.F.; Zhu, B.Q.; Xu, B.; Ma, Z.B.; Liu, J.Q. Recharge to the inter-dune lakes and Holocene climatic changes in the Badain Jaran Desert, western China. Quat. Res. 2010, 73, 10-19. [CrossRef]

55. Ma, J.Z.; Edmunds, W.M. Groundwater and lake evolution in the Badain Jaran Desert ecosystem, Inner Mongolia. Hydrogeol. J. 2006, 14, 1231-1243. [CrossRef]

(C) 2020 by the authors. Licensee MDPI, Basel, Switzerland. This article is an open access article distributed under the terms and conditions of the Creative Commons Attribution (CC BY) license (http://creativecommons.org/licenses/by/4.0/). 